\section{Birlesik Dünya Arastırma New Trends and Issues BD-CENTER Proceedings on Humanities and \\ Innovasyon ve Yayıneılık Merkezi \\ Social Sciences}

Volume 8, Issue 2, (2021) 49-58

\title{
Impact of digitalisation of education on human capital development
}

\author{
Maira Suteyeva*, Aktobe Regional State University named after K. Zhubanov, Aktobe, Kazakhstan \\ Lazzat Sarsembayeva, Aktobe Regional State University named after K. Zhubanov, Aktobe, Kazakhstan
}

\section{Suggested Citation:}

Suteyeva, M. \& Sarsembayeva, L. (2021). Impact of digitalisation of education on human capital development. New Trends and Issues Proceedings on Humanities and Social Sciences. 8(2), 49-58. Available from: www.prosoc.eu

Received from June 21, 2021; revised from July 22, 2021; accepted from September 13, 2021.

Selection and peer review under responsibility of Prof. Dr. Huseyin Uzunboylu, Higher Education Planning, Supervision, Accreditation and Coordination Board, Cyprus.

${ }^{\circ} 2021$ Birlesik Dunya Yenilik Arastirma ve Yayincilik Merkezi. All rights reserved.

\begin{abstract}
The article deals with the main issues of digitalisation of Kazakhstan's education as a key policy of the state. The ongoing reforms are based on the development of human capital. The purpose of this publication is to highlight the results of the theoretical and experimental parts of the study. The methods used in this paper include analysis of psychological, pedagogical, socio-economic and technical literature on the research problem comparatively. From the results, it is worth noting a new level of communication between the teacher and the student, which goes beyond the classical one. These include communication features such as WhatsApp, Zoom, Messenger, email and Instagram, among others. In this regard, improving digital literacy at all levels of the education system is becoming a priority. Some recommendations made are to fill the network with a variety of information and to use modern information and communication technologies to provide a whole range of tools for communication between teachers and students.
\end{abstract}

Keywords: Internet, social networks, mobile application, IT technologies, human capital, education, smart devices.

\footnotetext{
* ADDRESS FOR CORRESPONDENCE: Maira Suteyeva, Aktobe Regional State University named after K. Zhubanov, Aktobe, Kazakhstan.

E-mail address: gv7072@mail.ru
} 


\section{Introduction}

Recent decades have created an undeniable incentive for the introduction of digital technologies in the world society, thereby forming the information society. Ignatova (2017) emphasises that the information society changes the ontology of education because the space (topos) and time of the lifeworld (temporality) of a person change. In the information society, changes are observed at the level of the deep basis of time, manifested in the desynchronisation of processes in real and virtual reality (Ignatova, 2017).

As is known, 'Digital Kazakhstan' 2018-2022 has five key areas: 'Digitalisation of economic sectors', 'Transition to a digital state', 'Implementation of the Digital Silk Road', 'Development of human capital' and 'Creation of an innovative ecosystem' (Gosudarstvennaya programma 'Tsifrovoy Kazakhstan' na 2018-2022 gody, 2018). Within the framework of the education system, the direction of human capital development remains a priority. This direction is aimed at creating a productive society in which the knowledge and skills of the future are cultivated from a very young age, the efficiency and speed of doing business are increased through automation and other new technologies, and the dialogue between citizens and the state becomes open and direct.

Currently, the level of digital literacy of the population of Kazakhstan is $76.2 \%$. In light of the global pandemic events, its growth is becoming a top priority for both the entire state and the Kazakh education system.

In this direction, over the past decades, the process of modernisation of Kazakhstan's schools has marked a sufficient share of innovative and financial transformations for the introduction and development of modern information and communication technologies (ICT) in the educational process. Progress in the development of Internet technologies has led to the replacement of the 'ancient' computer with modern devices, such as tablets or smartphones and smart devices.

The aim of the research is to study the possibilities of digitalisation of Kazakhstan's education, which affects the development of human capital on the example of students and teachers of pedagogical specialties of the ARU named after K. Zhubanov and Baishev University. The object will be the process of digitalisation of the education system itself and the subject will be the digitalisation of Kazakhstan's education and the development of human capital. The purpose of this publication is to highlight the results of the theoretical and experimental parts of the study.

\section{Methods and materials (experimental)}

Analysis of psychological, pedagogical, socio-economic and technical literature on the research problem; comparative and system structural analysis; sociological survey and questionnaire were carried out.

\section{Theoretical basis of the study}

It is necessary to highlight the reports of international studies on the development of digitalisation of society. So, Soldatova and Rasskazova (2015) and Holloway, Green and Livingston (2013) identified the degree of importance of owning and having the latest version of IT products for young people. Gosudarev (2013), Grigor'yev (2005), Golubev and Nikiforov (2012) and Makarchuk (2013) investigated the main categories for identifying the potential of mobile technologies in school education. Andreyev (1995), Voronkin (2014), Grigor'yev (2005), Ellison (2007) and Manca and Ranieri (2013) presented to the scientific community works on the use of mobile technologies as a unique element of education reform. Baymakhanova, Baymakhan and Summers (2020) reflected the features of the use of open educational resources in the context of the levels of the Kazakh education system. The presented results of scientific products do not reflect the full picture of the scientific research carried out in the world on the digitalisation of society and education, which affects the development of human capital. 
Within the framework of this publication, we have reflected only on the topics that, in our opinion, reflect its scientific side.

Let us consider the main stages of the formation of the digitalisation of the Kazakh society, and with it the education system.

The first stage is characterised by the beginning of the 1980s, where in 1984 Decree No. 13-XI 'On the Reform of General and vocational education' was first adopted (Ukaz № 13-XI 'O reforme obshchego i professional'nogo obrazovaniya', 1984). Since this period, the entire education system of the then Soviet Union began to be equipped with the first computers, which served as the basis for the development of information and technical literacy of society. This served as the basis for the reform of education, where a new course 'Computer Science' was introduced in secondary schools (grades 5-11), primary courses of the university and a new specialty 'computer science teacher' appeared. In parallel with the innovations, there were many hindering factors: a significant gap between educational organisations in the context of urban-rural areas, pedagogical and parental readiness to restructure thinking and lack of foresight of scientific and technological progress in the development of ICTs and their capabilities.

The second stage of digitalisation of education and development of human capital fell on the first years of the post-Soviet period (approximately 1990-1999), especially for Kazakhstan. As for the other countries of the former Soviet Union, they aimed at restoring socio-economic and political stability. In this regard, the process of reforming the education system, as well as the issues of its digitalisation, was chaotic and unstable during this period.

The third stage of the development of digitalisation of Kazakhstan's education and human capital is the period from 1999 to 2015. This period is marked by high-quality and interesting research in this direction, new technical developments (for example, Intel and Microsoft, Apple, Tesla and others), the possibility of robotisation in the education system and in the industrial sphere - the introduction of automated devices and devices that facilitate the work of society.

The current period of development of digitalisation of Kazakhstan's education and human capital (from the end of 2015 to the present) is characterised by large IT projects: digitalisation of the world community, transition to crypto-circulation, development and operation of electric vehicles, design of residential buildings with the use of geothermal heat (solar and wind energy), transition to distance learning and so on. The educational environment is equipped with smartphones, androids, various kinds of tablets and other smart devices. The transfer of everyday practices related to the use of ICT into the educational process leads to its transformation of the values of education, which is still one of the problematic issues that cause scientific interest for the possibility of research.

Thus, summing up the results of this period, as noted in the OECD report 'Measuring Innovation in Education', Kazakhstan has made significant progress in the transition to a model of education with digital support due to the improved availability of computer and Internet infrastructure in all institutional landscapes of the country ('Izmereniye innovatsiy v obrazovanii' Otchet OESR, 2014).

\section{Results}

\subsection{Review of previous research conducted in the world}

In Estonia, back in 1996, the Tiger Leap Programme was launched, which was based on three main directions: providing all schools with computers and Internet, basic training of teachers and conducting electronic courses in Estonian for general education institutions. As a result, in 2000, all schools in Estonia were equipped with computer equipment, and by the following year 2001 they had Internet access (HITSA Information Technology Foundation for Education, 1997-2000). In fact, the widespread use of the online platform in Estonian schools was a key factor that allowed the country to ensure a smooth 'painless' transition to distance learning during the global lockdown. It is worth 
taking into account that not just the coronavirus can transform our usual reality. For example, in Kazakhstan, there are severe winters inherent in the northern regions of the country, which does not allow schoolchildren to attend classes at a certain period of time every day, and this also negatively affects the quality of education in general.

In Russia, the SKOLKOVO business trend, the Centre for Educational Developments of the SKOLKOVO Business School translated the 2017 report for the Russian-speaking audience and reviewed 10 key trends of transformation in the educational sphere (10 trendov budushchego obrazovaniya, 2017).

1. The introduction of progressive teaching methods requires cultural transformation.

2. Training in real practical skills will improve professional qualifications.

3. Cooperation is a key factor in the dissemination of effective solutions as its ability to cooperate in the global market.

4. Despite the widespread use of technologies and materials for online learning, they are still not available to everyone.

5. It is necessary to create processes for assessing skills at the individual level.

6. It is not enough just to be able to use technologies in order to feel free in the digital world.

7. The effectiveness of online learning, as well as mobile and mixed learning, is beyond doubt.

8. Educational ecosystems should be flexible enough to accept completely new teaching methods.

9. Higher education is an excellent environment for developing more intuitive computers.

10. Continuous learning is the basis of higher education.

According to the results of the Class Central study, in 2016, educational platforms were presented by more than 700 universities, 6,850 courses and 58 million students were trained on them. According to the College Data website, the average university has from 5,000 to 15,000-20,000 students; the Coursera educational platform has 23 million students; EdX has 10 million; Xuetang $X$ (the first nonEnglish-speaking platform that entered the top 5 leading MOE in the world) has 6 million; Future Learn has 5.3 million; and Udacity has 4 million.

Let us consider the results of an independent sociological study conducted by teachers of Baishev University and Aktobe Regional University named after K. Zhubanov with students of the first and second years and teachers of pedagogical disciplines. A total of 47 students and 11 teachers of Baishev University and 74 students and 19 teachers of Aktobe Regional University named after K. Zhubanov took part in the survey. In total, 121 students and 30 teachers took part in the study. The purpose of the survey is to clarify the attitude of students and teachers towards the processes of digitalisation in their studies and everyday life.

The questionnaire consisted of 20 questions, of which we will focus on the results of 3 important questions in the opinion of the authors:

1. What do you mean by the concept of 'Digitalisation of society?'

- The use of IT devices in all industries and spheres of activity to improve the quality of life of society.

- The use of information technologies by young people and schoolchildren for obtaining quality education.

- Social adaptation of society to the new realities of life.

- Others.

2. Does the use of information technology and the Internet give you the opportunity to gain high-quality knowledge?

- Yes

- No 
3. Do you think that the possession of IT competencies at a sufficient level is necessary in modern society?

- Yes

- No

Speaking about the choice of characteristics of the concept of 'Digitalisation of society' among students and teachers of the selected universities of the Aktobe region, more than half of the respondents (49.4\%) noted that it is 'the use of IT devices in all industries and spheres of activity to improve the quality of life of society'. One-third (31.7\%) of the respondents noted that this is 'the social adaptation of society to the new realities of life' and one-tenth of the opinions were divided between the following statements: 'the use of information technologies by young people and schoolchildren to obtain a quality education' (9.8\%) and 'a different understanding of the concept' (9.1\%).

The results of the groups of students are shown in Figure 1.

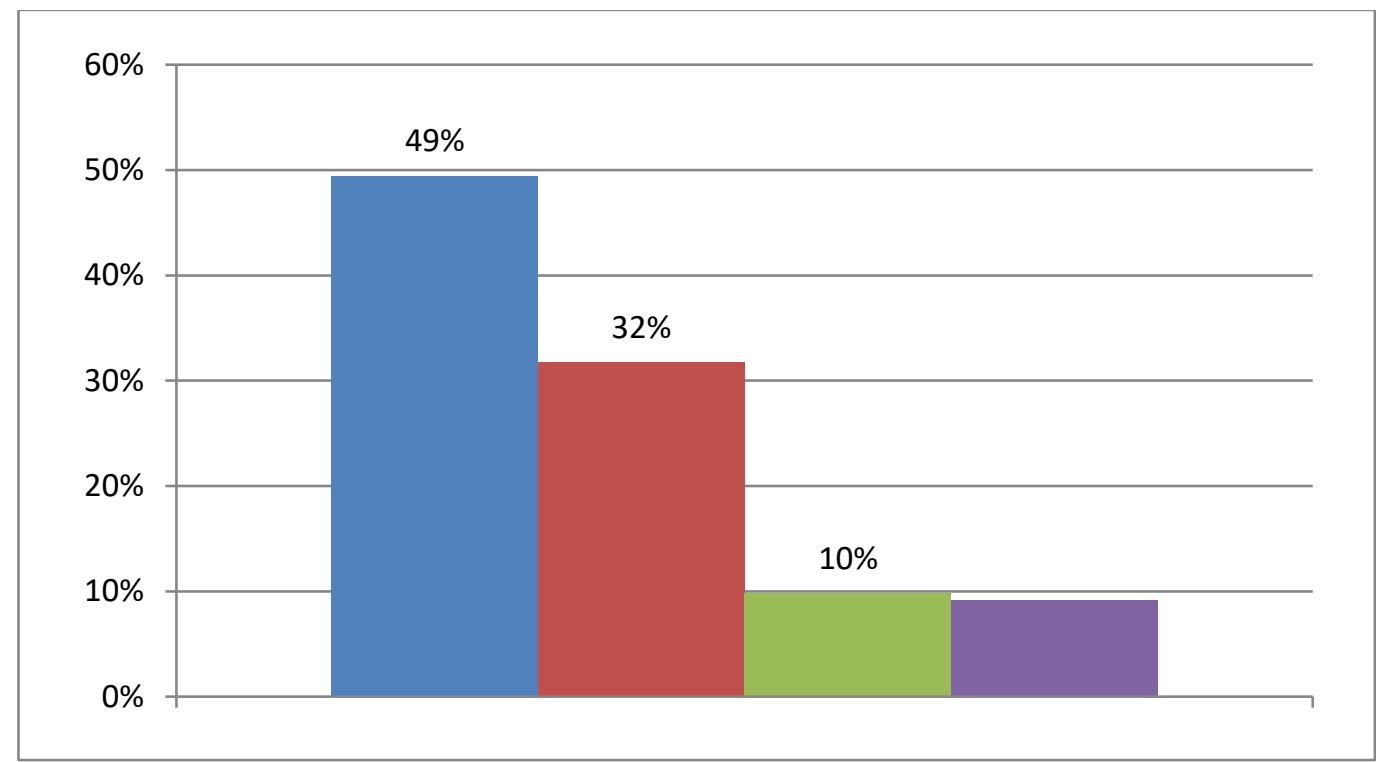

Figure 1. Results of the sociological survey on the choice of characteristics of the concept of 'Digitalisation of society'

According to the results of the other two questions, it should be noted that about $82 \%$ of the respondents were inclined to give a positive answer to the questions that the use of information technologies and the Internet gives you the opportunity to obtain high-quality knowledge and the possession of IT competencies is necessary at a sufficient level in modern society.

At the same time, groups of teachers with a greater or lesser share of developed IT competencies were identified as follows:

- Using new technologies randomly (about 13\%);

- Forced use of ICT technologies (about 75\%)

- Groups of innovative teachers (about 12\%) (Figure 2). 


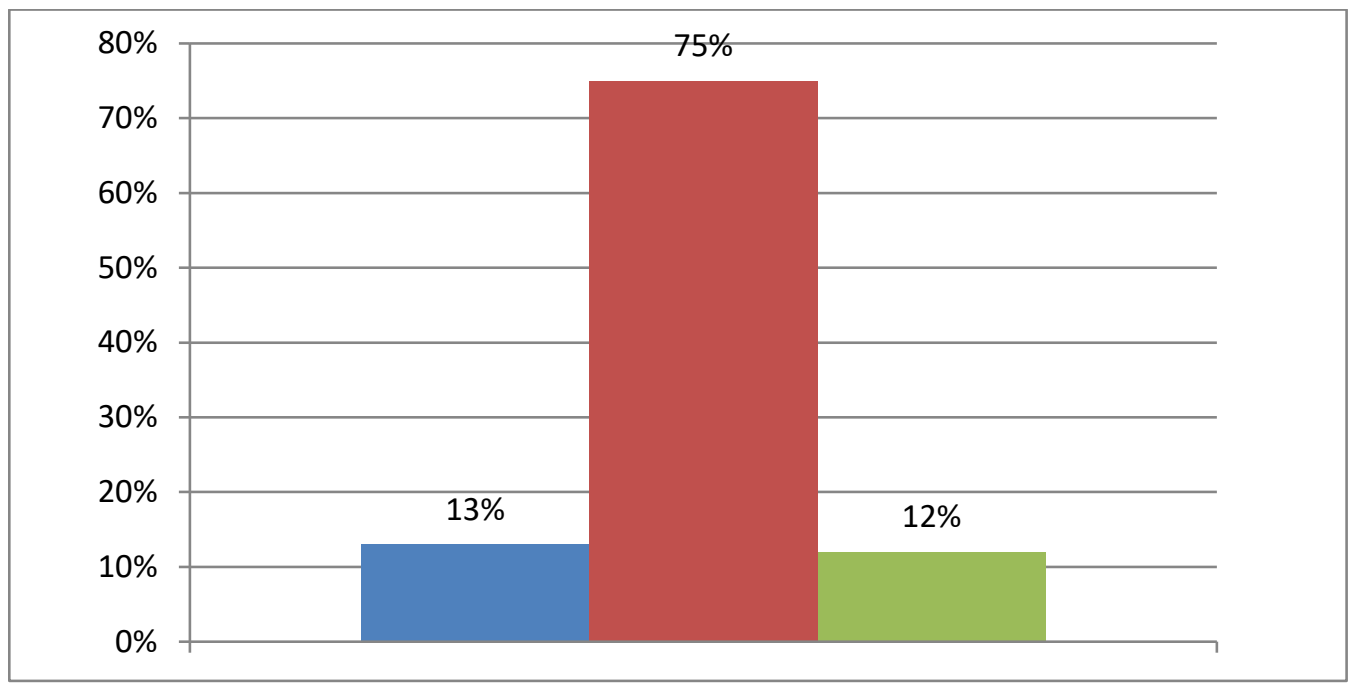

Figure 2. Results of the sociological survey of teachers to identify the level of formation of IT competencies

Thus, the presented results indicate that at present the society reacts positively to the innovative processes associated with the digitalisation of society and education as an important component for the development of the human capital in the Republic of Kazakhstan.

When conducting a blitz survey on 'How did the situation with the coronavirus affect your information literacy?', all participants of the pedagogical experiment responded positively, with an increase in $50 \%$ (Table 1).

Table 1. Results of the blitz survey on 'How did the situation with the coronavirus affect your information literacy?'

\begin{tabular}{lcccccccc}
\hline & \multicolumn{3}{c}{ Before the pandemic } & \multicolumn{3}{c}{ During the pandemic and beyond } \\
\hline & $\begin{array}{c}\text { Social } \\
\text { networks }\end{array}$ & $\begin{array}{c}\text { Ready- } \\
\text { made IT } \\
\text { products }\end{array}$ & $\begin{array}{c}\text { Authors } \\
\text { of IT } \\
\text { products }\end{array}$ & $\begin{array}{c}\text { Blended } \\
\text { learning }\end{array}$ & $\begin{array}{c}\text { Social } \\
\text { networks }\end{array}$ & $\begin{array}{c}\text { Ready- } \\
\text { made IT } \\
\text { products }\end{array}$ & $\begin{array}{c}\text { Authors } \\
\text { of IT } \\
\text { products }\end{array}$ & $\begin{array}{c}\text { Blended } \\
\text { learning }\end{array}$ \\
\hline Students & $70 \%$ & $35 \%$ & $11 \%$ & $7 \%$ & $96 \%$ & $51 \%$ & $48.9 \%$ & $100 \%$ \\
Teachers & $37 \%$ & $38 \%$ & $17 \%$ & $9.3 \%$ & $77 \%$ & $67 \%$ & $75 \%$ & $100 \%$ \\
\hline
\end{tabular}

The obtained data show how much the situation in the world has changed and how it has affected the thinking of the student and teacher. We see that before the pandemic, both students and teachers' opinions about IT were mainly subjective and depended on personal capabilities. While the situation with the coronavirus and the current state in the world society forced everything to change, beginning with mastering the skills of information literacy in a short time.

The coronavirus global situation has determined a new policy of higher education, namely the transition to mixed education. This pattern is observed not only in Kazakhstan, but in almost all universities of the world.

With shifting the perspective towards the digitalisation of Kazakhstan's education, it is necessary to highlight the following information:

1. Taking into account the capabilities of IT devices for modern education: smartphones, laptops, tablets and other mobile devices.

2. The use of Internet resources in teaching and learning (Feshchenko, 2011; Manca \& Ranieri, 2013). These include not only social networks as a means of communication, but also educational portals. 
3. Prevention of psychological resistance of consumers of digitalisation aimed at preserving human capital. In this perspective, we can distinguish modern research on the concepts of 'cyberstability', 'cyberpedagogy' and 'cyberpsychology'.

4. The quality of the technical capabilities of digitalisation: at home, in a building, on the street, in rural areas, in vehicles etc. This category, with all the possibilities of the Internet, still leaves much to be desired.

\section{Discussion}

When discussing the issue of digitalisation of Kazakhstan's education, it should be noted that the latest global trends have pushed all participants in the pedagogical process to step up their efforts towards improving information competence.

It is also worth noting that there is a new level of communication between the teacher and the student, which goes beyond the classical one. These include communication features such as WhatsApp, Zoom, Messenger, email and Instagram, among others. In this case, we should talk about 'cold' communication.

On the other hand, both the teacher and the student have an additional burden - more time spent at the computer and on the web of the Internet. In this case, we should talk about the mental stability of the individual, the expansion of didactic opportunities, the choice of new methods and techniques of teaching.

Also, in the course of the conducted pedagogical research, we carried out searches for the following questions:

- What are the theoretical and practical foundations of digitalisation of education in the Republic of Kazakhstan and abroad?

- What is the essence of the concepts of 'digital education', 'digital pedagogy' and 'information culture'?

- What are the methodological foundations of the students' information culture?

- What are the possible prospects and risks of digitalisation of modern education in the Republic of Kazakhstan?

- What is the degree of knowledge of the psychological stability of students to the digitalisation of their learning system?

- What is included in the list of force majeure and unforeseen circumstances in the system of Kazakhstan education?

The answers to the questions posed cannot be final. In our opinion, the world is currently unstable and information is becoming outdated every minute. Also, global situations, such as the coronavirus, political and ideological events of a particular country, have a huge impact. Along with these issues, also taking into account the current global situation, we should note the advantages of digitalisation of education and its impact on the development of human capital. First, as we have already noted above, there is an increase in the level of information literacy of society. Secondly, the system of blended learning allows simplifying the issues of international academic mobility of the teaching staff, allowing the best professors and lecturers to speak remotely and unite several classrooms. Third, the expansion of the framework of self-education has influenced the development of new online courses, internships and professional competitions. Fourth is the communication without borders and internationalisation of education.

We have indicated only the main positive aspects of digital education, the list of which can be continued (for example, online meetings with parents of students, opportunities for inclusive education etc.).

However, at the same time, we must pay attention to the research and issues of cyberstability of the individual, psychological Internet addiction and so on. 


\section{Conclusion}

The presented brief review of theoretical data and a sociological survey pointed to the consumer potential of social networks as a potentially new resource. These resources ensure the organisation of pedagogical interaction, both in the educational process and beyond, allowing the use of elements of educational technologies and thereby increasing the involvement of students in the process of learning and learning. In general, the preliminary results of the study allow us to distinguish two ways of using social networks in Kazakhstan society, as well as in the whole world community. These include:

1. A special information service to support and implement existing forms of teaching and learning;

2. A form of the educational process aimed at continuous improvement of IT competencies in order to be 'in touch' with the rapidly changing world.

The positive aspects include the variability of the use of social networks for educational purposes, in both student activities and teaching. The aspects that require special attention include the still low level of literacy in the IT field and the inertia of the transition from the traditional form of work to the digitalised one, which also requires time to review its regulatory regulations. This group includes the level and quality of technical capabilities of Kazakhstan's IT companies.

Thus, the data obtained during the pandemic showed the limitations of the use of social networks in education. This is mainly due to the low Internet speed, the lack of access to some information sites and the blocking of resources that require payment for use. Moreover, it affects the unprocessed teaching methods for working in social networks and effective forms of using mobile technologies; there are no tools for assessing the quality of education to determine the level of formation of social, communication and information competence of all participants in the pedagogical process. Special attention should be paid to the psychological aspect of conducting classes online, where the teacher does not see the student's concentration on new information. However, despite all the abovementioned problematic points, teachers note the fact that in the framework of distance education the most successful of the pedagogical technologies is project activity or group or pair work.

\section{Recommendations}

Project activities or extracurricular activities give students the opportunity to share responsibility for making decisions, solving problems among themselves and resolving conflicts of ideas. According to the theory of development, this type of activity corresponds to interpersonal communication - the leading type of activity for adolescents. Project activities include problem formulation, algorithm creation, monitoring and evaluation, support and evaluation that encourage cognitive development. New technological advances in the field of ICT can help students develop digital skills and abilities in project activities.

The main recommendations for teachers, in our opinion, are the ability to work with IT devices, to consider new didactic methods and forms of working with students in the context of digitalisation of society. An equally important recommendation is the question of psychological stability and psychological perception of the individual.

Thus, considering the issue of digitalisation of Kazakhstan's education and the development of human capital, it is necessary to point out the trends that are being carried out in terms of political transformations in the education system. These include approved state programmes that cover education issues, including the adoption of IT resources by the Kazakh community to create the comfort of their lives. Among the possibilities of using modern educational technologies, one can find a large number of relevant methods aimed at teaching students to learn professional and educational content independently, as well as the teacher himself to be able to vary both his ICT capabilities and 
the student's knowledge of IT programmes, skilfully operating them in the semi-pause of quality education.

\section{References}

Andreyev, A. A. (1995). Sovremennyye telekommunikatsionnyye sistemy $v$ obrazovanii [Modern telecommunication systems in education]. Pedagogicheskaya informatika [Pedagogical Informatics], 1, 55-63. (in Russian).

Baymakhanova, G. K., Baymakhan, S. N. \& Sammers, D. (2020) Otkrytyye obrazovatel'nyye resursy v obrazovanii: effektivnost', targeting, perspektivy [Open educational resources in education: efficiency, targeting, prospects]. Vestnik Karagandinskogo universiteta. Seriya [Pedagogika - Bulletin of Karaganda University. Series 'Pedagogy'], 2(98), 46-53. (in Russian).

Ellison, N. (2007). Social network sites: definition, history, and scholarship. Journal of Computer-Mediated Communication, 13(1), 5-25.

Feshchenko, A. V. (2011). Sotsial'nyye seti v obrazovanii: analiz opyta i perspektivy razvitiya [Social networks in education: analysis of experience and development prospects]. Otkrytoye distantsionnoye obrazovaniye [Open Distance Education], (3), 44-50. (in Russian).

Golubev, O. B. \& Nikiforov, O. Y. (2012). Smeshannoye obucheniye v usloviyakh tsifrovoy shkoly [Blended learning in a digital school]. Sovremennyye problemy nauki i obrazovaniya [Modern problems of science and education], (6), 374. (in Russian).

Gosudarev, I. B. (2013) Elektronnoye obucheniye: tendentsii razvitiya modeley i opyt primeneniya [E-learning: trends in the development of models and experience of application] (pp. 162-166). Izvestiya Rossiyskogo gosudarstvennogo pedagogicheskogo universiteta im. A. I. Gertsena [Bulletin of the Russian State Pedagogical University. A. I. Herzen]. (in Russian)

'Gosudarstvennaya programma Tsifrovoy Kazakhstan' na 2018-2022 gody [State program 'Digital Kazakhstan' for 2018-2022]. (2018). [Elektron. resurs]. Retrieved from https://digitalkz.kz/ (in Russian).

Grigor'yev, S. G. (2005). Informatizatsiya obrazovaniya [Informatization of education]. Fundamental'nyye osnovy [Fundamentals] (p. 231). Moscow, Russia: MGPU. (in Russian).

HITSA Information Technology Foundation for Education. (1997-2000). Retrieved from https://www.hitsa.ee/ about-us/historical-overview/

Holloway, D., Green, L. \& Livingstone, S. (2013). Zero to eight: young children and their Internet use (p. 127).

Ignatova, N. Y. (2017). Obrazovaniye $v$ tsifrovuyu epokhu: monografiya [Education in the digital era: monograph] (p. 128). Nizhniy Tagil, Russia: NTI (filial) UrFU. (in Russian).

'Izmereniye innovatsiy v obrazovanii' Otchet OESR. ['Measuring Innovation in Education' OECD Report]. (2014) [Elektron. resurs]. Retrieved July 7, 2014, from https://oecdru.org/ (in Russian).

Makarchuk, T. A. (2013). Mobil'noye obucheniye na baze snezhnykh uslug [Mobile learning based on snow services]. Sovremennyye problemy nauki i obrazovaniya [Modern Problems of Science and Education], 2. (in Russian).

Manca, S. \& Ranieri, M. (2013). Is it a tool suitable for learning? A critical review of the literature on Facebook as a technology- enhanced learning environment. Journal of Computer Assisted Learning, 29(6), 487-504.

Soldatova, G. U. \& Rasskazova, E. I. (2015). Modeli peredachi opyta mezhdu pokoleniyami pri osvoyenii i ispol'zovanii Interneta [Models of transfer of experience between generations in the development and use of the Internet]. Voprosy psikhologii [Questions of psychology], 2, 56-66. (in Russian).

10 trendov budushchego obrazovaniya [10 trends for the future of education]. (2017). Retrieved from http://trends.skolkovo.ru/2017/10/10-trendov-budushhego-obrazovaniya/ (in Russian)

Ukaz № 13-XI 'O reforme obshchego i professional'nogo obrazovaniya' [Decree No. 13-XI 'On the reform of general and vocational education']. 1984. [Elektron. resurs]. Retrieved April 12, 1984, from http://www.consultant.ru/ (in Russian). 
Venger, A. L. \& Slobodchikov, V. I. (1988). Problemy detskoy psikhologii i nauchnoye tvorchestvo D. B. El'konina [Problems of child psychology and scientific work of D. B. Elkonin]. Voprosy psikhologii [Questions of Psychology], 3, 20-30. (in Russian).

Voronkin, A. S. (2014). Sotsial'nyye seti: evolyutsiya, struktura, analiz [Social networks: evolution, structure, analysis]. Obrazovatel'nyye tekhnologii i obshchestvo [Educational Technologies and Society], 17(1). (in Russian). 